1992

\title{
State-Federal Judicial Relationships: A Report from the Trenches
}

Ellen Ash Peters

University of Connecticut School of Law

Follow this and additional works at: https://opencommons.uconn.edu/law_papers

Part of the Jurisdiction Commons

\section{Recommended Citation}

Peters, Ellen Ash, "State-Federal Judicial Relationships: A Report from the Trenches" (1992). Faculty Articles and Papers. 317. https://opencommons.uconn.edu/law_papers/317 


\section{HEINONLINE}

Citation: 78 Va. L. Rev. 18871992

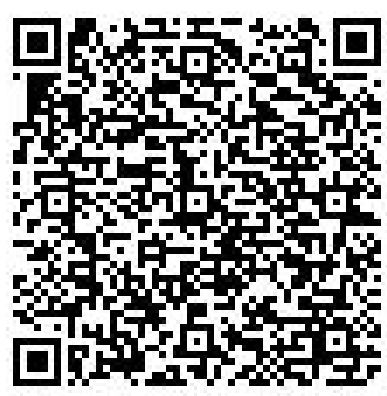

Content downloaded/printed from HeinOnline (http://heinonline.org)

Tue Aug 16 13:03:25 2016

-- Your use of this HeinOnline PDF indicates your acceptance of HeinOnline's Terms and Conditions of the license agreement available at http://heinonline.org/HOL/License

-- The search text of this PDF is generated from uncorrected OCR text.

-- To obtain permission to use this article beyond the scope of your HeinOnline license, please use:

https://www.copyright.com/ccc/basicSearch.do? \&operation $=$ go\&search Type $=0$ \&lastSearch $=$ simple\&all $=$ on\&titleOrStdNo $=0042-6601$ 
STATE-FEDERAL JUDICIAL RELATIONSHIPS: A REPORT FROM THE TRENCHES

\author{
Ellen A. Peters*
}

$\mathrm{T}$

TE organizers of the National Conference on State-Federal Judicial

Relationships presented the conference participants with a dual-track learning experience to acquaint them with the issues confronting dual sovereignty in the late twentieth century. Throughout the meeting days, the conferees heard a substantial number of formal presentations and commentaries, many reprinted elsewhere in this issue of the Virginia Law Review, about the strengths and weaknesses of state and federal judicial interactions. On several occasions the conferees themselves met im small group sessions designed to elicit dialogne and programmatic suggestions for improving state-federal relations. Fifteen small groups engaged in spirited discussions under the leadership of gifted facilitators, ${ }^{1}$ who encouraged widespread participation while focusing attention on a goal-directed agenda. The undertakings of the small groups were recorded by diligent reporters ${ }^{2}$ whose work product was assembled by three chief reporters.

On the final day of the conference, each of the three chief reporters presented an overview of the activities of the small group sessions. Professor Paul D. Carrington, the Harry Chadwick Professor of Law at Duke Umiversity School of Law, placed the discussions into a broad frame of reference, emphasizing the need for effective, healthy judicial institutions that generate trust and confidence. He observed that state courts labor under chronic funding disadvantages that have been exacerbated by the burgeoning demands of such global concerns as the drug crisis. Judge J. Clifford Wallace, Chief Judge of the United States Court of Appeals for the Ninth Circuit, described and summarized small group discussions insofar as they focused on the strategic structural role of state-federal councils. Such councils, at a local, state, and national level, have helped to foster a climate of cooperation rather than competition between our two court systems. My responsibility was to present an overview of the remaining work product of the small groups, to identify the controversies that were the focal poimts of sniall group discussions, and to summarize the concrete solutions that

* Ellen A. Peters is Chief Justice of the Supreme Court of Connecticut. Before becoming a judge, she was a member of the faculty of the Yale Law School for twenty-two years.

1 The facilitators were state and federal appellate and trial judges and court administrators.

2 The reporters were noted law faculty selected for their special interest in state-federal issues. 
appealed to the conferees as ways to minimize inherent frictions in statefederal judicial relations.

The work product of the small group conferees can be described, following the suggestion of one of the participants, as responding to three questions: (1) Has something been perceived as a problem in state and federal judicial relationships that in fact is not a problem? (2) Are there new problems in state and federal judicial relationships that need to be addressed? and (3) Can we develop new and concrete approaches to resolving old and new problems in state and federal judicial relationships?

The legal literature suggests that two questions of state-federal judicial relationships are of paramount importance, one relating to federal jurisdiction arising out of diversity of citizenship and the other relating to federal jurisdiction arising out of the writ of habeas corpus. Most of the small groups did not dwell at length on either of these jurisdictional issues per se.

Because there is httle likelihood that diversity jurisdiction will be abolished in its entirety in the near future, federal jurisdiction to entertain such cases is a fact of life for federal and state judges alike. Many federal judges enjoy the subject matter of the cases that the diversity docket brings to them and therefore favor retention of this jurisdiction. State court judges, confronted with overcrowded dockets and inadequate resources, liave no urgent need to reach out for new business, even though many of thein are philosophically opposed to the existence of federal diversity jurisdiction.

Federal supervision of state criminal cases througl federal habeas corpus hitigation is a process that state judges view with a mixture of displeasure and equanimity. Although some judges in both judicial systems favor restricting access to the Great Writ, no one advocates its abohtion. The fact that forty percent of state convictions involving capital crimes are overturned as a result of federal habeas corpus proceedings ${ }^{3}$ contimues to provide telling evidence of the constitutional madequacy of some state procedures, especially those relating to the appointment of well-funded and well-prepared legal counsel. The judges recognized, however, that reeent decisions of the United States Supreme Court, curtailing the scope of federal habeas, have reduced some of the friction generated by the availability of the writ. ${ }^{4}$

Altliougli the conferees accepted the existence of federal jurisdiction over diversity cases and writs of habeas corpus, they expressed deep concern

3 Ronald J. Tabak \& J. Mark Lane, Judicial Activism and Legislative Reform of Habeas Corpus: A Critical Analysis of Recent Development and Current Proposals, 55 Alb. L. Rev. 1, 11 (1991).

4 See generally id. (discussing recent habeas corpus reforms). 
about the abiding adverse consequences of this jurisdiction for the reputation of the state courts. Throughout the conference, reports from litigants, attorneys, and scholars highlighted this problem by questioning tlie independence and rectitude of state court judges. For example, Professor Martim Redish observed, in his "Martian Chromicle," that "in certain types of litigation, most state courts slould be deemed considerably less fair than their federal counterparts." The imphications of such an adverse perception for effective case management were spelled out in Victor Flango's paper on 'Attorneys' Perspectives on Choice of Forum in Diversity Cases." 6 Althougl no conferce was prepared entirely to deny the possibility of structurally generated bias in state courts, some judges cautioned that local bias may represent divisions, not along state lines, but between downstate and upstate, between urban and rural constituencies within the state. The judges repeatedly emphasized, however, that a perception of state court madequacies, often relating to past practices and procedures that liave long ago been rectified, serves to undermine the broad base of support, especially financial support, that state courts urgently need in order to continue to improve their operations for the future.

\section{II}

Emerging problems of state and federal jurisdiction that have recently appeared on judicial horizons largely have their origins in specific federal statutes rather than in overarching federal constitutional principles. An illustrative list of federal statutes that have the potential to create problems for state courts imcludes federal antidiscrimination statutes, the federal bankruptcy act, and proposed federal legislation for the creation of a federal cause of action to combat family violence and for the consolidation of mass torts in the federal courts. ${ }^{7}$

Drafted with general language of uncertain scope, federal antidiscrimination statutes raise questions about the functioning of state courts. This issue is illuminated by thrce cases decided by the Umited States Supreme Court in 1991. The Age Discrimination im Employment Act, which broadly outlaws mandatory retirement for all employees, ${ }^{8}$ including tlose employed by state

5 Martin H. Redish, Reassessing the Allocation of Judicial Business Between State and Federal Courts: Federal Jurisdiction and "The Martian Chrouricles," 78 Va. L. Rev. 1769, 1779 (1992). Professor Redish's observation was specifically addressed to state adjudication of a federal constitutional claim asserted by a private party against the state or one of its agents.

6 Victor E. Flango, Attorneys' Perspectives on Choice of Forum in Diversity Cases, 25 Akron L. Rev. 41 (1991).

7 Correlatively, federal statutes to create federal criminal jurisdiction for felonies involving handguns have the potential to create problems for the federal courts.

829 U.S.C. $\$ \S 623(\mathrm{a}), 631$ (a) (1988). 
governments, called into question the tenure of appointed state judges. ${ }^{9}$ In Gregory v. Ashcroft, ${ }^{10}$ the Court held that the statute should not be construed as having imphedly preempted state constitutional provisions requiring retirement at the age of $70 .{ }^{11}$ The Voting Rights Act, which invalidates all state electoral practices that impair the opportunity of racial groups "to participate in the political process and to elect representatives of their choice,"12 challenged the procedures governing the election of state judges. In Chisom v. Roemer ${ }^{13}$ and Houston Lawyers' Ass'n v. Attorney General of Texas, ${ }^{14}$ the Court decided that Congress had intended to include judges within the term "representatives" and that at-large eleetion of state judges might improperly dilute the electoral rights of minority voters. The conferees expressed their doubts about the wisdoin of such intrusion of federal law into long-established procedures for the election of state judges in a significant number of southern states.

The impact of the Bankruptcy Act on state judicial proceedings arises not out of new congressional action but out of the pervasiveness of the autornatic stay that is an immediate consequence of the filing of a bankruptcy petition. ${ }^{15}$ In recent times of fiscal adversity, the proliferation of bankruptcy petitions has complicated the inanagement of state dockets. In this area, conferees exchanged speeific suggestions to improve the flow of information between the federal and the state systems. Although all conferees agreed that the attorneys for bankrupt debtors should apprise state courts when a stay has been imposed or lifted, they beheved that a systematic channel of direct communication among the clerks of the respective courts would significantly improve caseflow in the state courts. The creation of such an information channel could be facilitated, as a matter of oversight, by statewide or local state-federal judicial councils. Furthermore, this information network could be impleinented by using coinputer technology to provide the appropriate state/federal interface.

On the horizon, proposed legislation raises new questions for both federal and state courts. The conferees repeatedly focused on two such proposals. Senator Joseph Biden's federal family violence bill, ${ }^{16}$ which would create a federal cause of action enforceable in state and federal courts, was seen as having the potential of adding to the congestion of the federal courts while

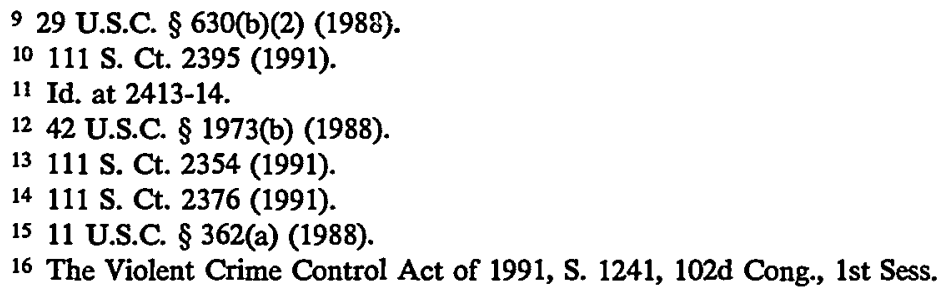


complicating the domestic relations agenda of the state courts. Pending legislative plans for consolidating complex mass tort litigation in the federal courts met with similar skepticism about tlie benefits to be gained from, and concern about the costs tliat may be associated with, a wide-ranging transfer of tort law out of the traditional ainbit of state jurisprudence. Several state judges recounted their disappointınent witl well-intentioned but frustrating efforts to consolidate state and federal asbestos litigation in designated federal courts. Their experience is consistent witl researcl studies that liave documented formidable obstacles to efficient and equitable resolution of asbestos-related personal mjury claims. ${ }^{17}$ Otlier conferees noted that the Conference on Uniform State Laws has promulgated a proposed Uniform Transfer Act tliat would retain state law as a governing principle while permitting consolidation of related litigation beyond state boundaries.

Emerging jurisdictional issues also affect the workload of the state and federal courts in criminal cases. The conferees noted that prosecutors often liave the choice to initiate criminal cases in either state or federal court. Although many state legislatures have recently enacted mandatory minimum sentencing statutes, the availability of the federal sentencing guidelines appears to be a strong mcentive for prosecutors to pursue criminal litigation in a federal forum. This imcentive may, im particular states, be reinforced by state court decisions interpreting state constitutions to provide greater procedural protection for criminal defendants than federal constitutional law currently affords. ${ }^{18}$

\section{III}

The small groups spent mucli of their tinie describing and inventing ways and means by whicl federal and state courts could preserve their independence while sharing information and resources. The conferees were fully persuaded of the desirability of working toward closer coordination between the two court systems. As Judge Williain W Schwarzer put it im his paper: "[S]tate-federal coordination . . . can pay off in furtliering economy, efficiency, and fairness ...."19 In addition to these systenic benefits, improved communieations betwecn state and federal judges, in professional as well as

17 See Deborah R. Hensler, Asbestos Litigation in the United States: A Brief Overview, in RAND Institute for Civil Justice, P-7776-ICJ (1992) and sources cited therein.

18 See, e.g., State Constitutions and Criminal Procedure: A Primer for the 21st Century, 67 Or. L. Rev. 689 (Ken Gormley ed., 1988); John Kincaid \& Robert F. Williams, The New Judicial Federalisin: The States' Lead in Rights Protection, 65 J. St. Gov't, Apr.-June 1992, at 50; Ellen A. Peters, State Supreme Courts in Our Evolving Federal Systen, 17 Intergovernmental Persp., Fall 1991, at 21.

19 William W Schwarzer, Nancy E. Weiss \& Alan Hirsch, Judicial Federalisin in Action: Coordination of Litigation in State and Federal Courts, 78 Va. L. Rev. 1689, 1750 (1992). 
social settings, will contribute significantly to a better understanding of the burdens of the two court systems and to greater respect for their achieveinents. Informed by mutual understanding and respect, intersystein coordination will be able to minimize the risk of vesting excessive control im either jurisdiction. The opportunity to exchange points of view during this conference reinforced the conferees' appreciation of the psychological as well as the imstitutional benefits of structured collaborative engageinents.

One recurrent obstacle to better state and federal cooperation is inertia. This conference has served to pave the way for any judge, state or federal, to take the initiative, to pick up the telephone, and to organize a coordinated agenda for overlapping state and federal judicial concerns. Nonetheless, at least one federal judge articulated the risk that his formal intervention on what might be characterized as "state turf" might be inisperceived as intrusive and patronizing, rather than as collegial and helpful. Although the best vehicle for ongoing iniprovement of state and federal judicial relations is undoubtedly a local or state judicial council, state judges may have to take the laboring oar to bring matters to such a council and to support its continued viability. In planning for better coordination, all judges must recognize, however, that they necd to make allies of the court administrators who inipleınent planning initiatives and, even more iniportant, of the attorneys and the hitigants who are the chents of the judicial system. Coordinated planning will take continued time and effort.

Several conferees einphasized that efficient problem solving can only take place within the proper frame of reference. Effective coordination of judicial resources must begin at the local level. As Chief Justice Paul J. Liacos put it at a small group session: "Don't inipose national solutions on local probleins!" Coordination will not produce miracles, but, with sufficient fiexibility and discretion, it will allow progress to be made toward reaching achievable goals.

On the local level, the conferees described a variety of specific problems of process and procedure, for which personal collaboration and technological interfacing between state and federal courts wonld assist the functioning of both court systeins. The conferees urged regular consultation that would permit the coordination of court calendars, juror hists, expert witness hists, and attorney discipline proceedings. Cooperative access to courtrooms and other court facilities would ease temporary space shortages in either court system. A systernic exchange of information would help to identify related cases pending in the two court systems, so that the courts could explore joint discovery procedures, joint motions practice, and joint settlement initiatives. The federal certification of issues of state law to state courts would be enhanced by agreeinent about procedures for the appropriate definition of novel questions of law by the federal courts and for their speedy resolution 
by the state courts. Joint educational programs, coordinating the efforts of the Federal Judicial Center and the National Judicial College, would stretch educational resources and facilitate the exchange of new ideas.

The coordination of local case management and the efficient use of local resources are concrete benefits that can readily be expected to flow from cooperative undertakings by state and local judges. Local courts cannot, however, operate effectively in the long run without sustained support on a national level. The conferces repeatedly emphasized their strong endorsement of joint planning on the national level for those issues that require a national focus. They agreed that state and federal judges must pool their energies so that the Federal Judicial Conference and the Conference of Chief Justices can jointly bring their influence to bear to inforn Congress about the costs associated with the federalization of state law and the limits on judicial immunity for state judges. ${ }^{20}$ To address the reality that the state judiciary is always at the bottoin of the fiscal priority hist, all judges should combine their voices to urge the American Bar Association to establish nationwide standards for the funding of state courts. Judges must team up to becoine more effeetive communicators about the appropriate deployment of scarce judicial resources with all of our audiences: our legislatures, our executives, the press, and the general public.

Finally, in returning to national issues, the conferces recognized that Inany state judicial systems are not well-positioned to move forward in dealing with the critical issues that will confront us in the years ahead. The foreseeability of a long period of scarce resources inakes it imperative, as Chief Justice Malcolm M. Lucas said in his keynote address, that we acknowledge that the job of judging has changed from being an arbiter within the courts to being an arbiter for the courts. ${ }^{21}$ Unless courts theinselves self-consciously take on the role of principal players in the nation's manageinent of its adjudicatory resources, others will take over the planning for us. That is a default position that neither the courts of this country, nor the people whoin we serve, can afford.

20 See Pulliam v. Allen, 466 U.S. 522 (1984).

21 Malcolm M. Lucas, Keynote Address: National Conference on State-Federal Judicial Relationships, 78 Va. L. Rev. 1663, 1669 (1992). 
